\title{
Low Grade Intraepithelial Neoplasia
}

National Cancer Institute

\section{Source}

National Cancer Institute. Low Grade Intraepithelial Neoplasia. NCI Thesaurus. Code C8367.

A precancerous neoplastic process that affects the squamous, glandular, or transitional cell epithelium without evidence of invasion. It is characterized by the presence of mild epithelial dysplasia. 